\title{
EVIDENCE FOR GONDWANAN ORIGINS FOR SASSAFRAS (LAURACEAE)? LATE CRETACEOUS FOSSIL WOOD OF ANTARCTICA
}

by

\author{
Imogen Poole ${ }^{1 *}$, Hans G. Richter ${ }^{2}$ \& Jane E. Francis ${ }^{1}$
}

\begin{abstract}
SUMMARY
Sassafrasoxylon gottwaldii sp. nov. is a new taxon for fossil wood with a suite of features diagnostic of Sassafras Nees \& Eberm. of the Lauraceae. The fossil wood described is from Late Cretaceous (SantonianMaastrichtian) sediments of the northern Antarctica Peninsula region. This new species of Sassafrasoxylon Brezinová et Süss resembles the species of extant Sassafras in being distinctly ring-porous, having vessel elements with simple perforation plates and very occasional scalariform plates with relatively few bars in the narrowest latewood vessels, alternate intervascular pitting, marginal (initial) parenchyma bands and paratracheal vasicentric parenchyma in the latewood, multiseriate rays and oil and/or mucilage cells. The fossils were found as isolated pieces of wood and therefore it is not certain whether the parent plant was Sassafras-like in all characters. Consequently the fossils have been placed in an organ genus rather than in extant Sassafras. This is the oldest record of an organ with features closest to extant Sassafras and may suggest that Sassafras first appeared in Gondwana and later radiated into the Northern Hemisphere. The distribution of extant Sassafras in North America and East Asia may represent a relict of a geographically more widespread taxon in the past.
\end{abstract}

Key words: Lauraceae, Sassafras, Antarctica, Cretaceous, wood anatomy, fossil.

\section{INTRODUCTION}

The lack of palaeofloras from mid-Cretaceous rocks from the Southern Hemisphere accounts for the dearth of knowledge about Gondwanan floristic diversity, angiosperm radiation and diversification. Studies of Southern Hemisphere Cretaceous fossils are needed to provide a more complete picture of floral diversity and dynamics through a period of global greenhouse warmth. Such studies will provide information pertinent

1) School of Earth Sciences, University of Leeds, Leeds, LS2 9JT, United Kingdom.

*) Present address: Wood Anatomy Section, Nationaal Herbarium Nederland, Utrecht Branch, P. O. Box 80102, 3585 CS Utrecht, The Netherlands.

2) Institute for Wood Biology and Wood Protection, Leuschnerstrasse 91, 21031 Hamburg, Germany. 
to the break-up of Gondwana and its influence on land plant evolution. The Antarctic Peninsula has probably the most complete Cretaceous sequence in the Southern Hemisphere but material from this sequence has not been studied extensively.

During the Late Cretaceous and Early Tertiary the Antarctic Peninsula was lying at a palaeolatitude of approximately $60-65^{\circ} \mathrm{S}$. Such a high latitude would have experienced a polar climate with short days and long periods of darkness followed by summers with continuous low-angle sunlight, coupled with a relatively mild temperature and ample moisture (Truswell 1991; Askin 1992; Francis 1996). Plant material, including wood, originating from vegetation that grew on the Antarctic Peninsula was washed into a sedimentary basin (the James Ross Basin) to the east. Subsequently it became waterlogged and buried within sediments that gradually filled the basin (Francis 1986; Pirrie et al. 1991; Pirrie 1994). The wood was infiltrated by calcium-rich solutions and petrified. These woods can be found in marine clastic sediments such as those now exposed on James Ross Island and Seymour Island.

This paper describes two calcified wood samples similar to Sassafras (Lauraceae) from the Late Cretaceous of Antarctica and forms part of an ongoing investigation of the fossil angiosperm wood flora of the northern Antarctic Peninsula region. These studies aim to determine changes in vegetation and climate, and to record trends in the evolution and specialization of secondary xylem through the Late Cretaceous and Early Tertiary.

\section{MATERIALS AND METHODS}

The fossil material illustrated in this paper is from two Late Cretaceous localities in the northern Antarctic Peninsula region. The type specimen (DJ. 1051.5), with an estimated diameter of at least $6 \mathrm{~cm}$, was found in the López de Bertodano Formation on Seymour Island. This Formation is dated as Maastrichtian based on ammonite zonation (Crame et al. 1991, 1999). The paratype (DJ. 451.6), with an estimated diameter of at least $12 \mathrm{~cm}$, was collected from the Santa Marta Formation, James Ross Island. This Formation is dated as mid-late Santonian to early Campanian based on dinoflagellates, ammonites and bivalves (Crame et al. 1991; Keating 1992).

The calcified wood specimens were thin-sectioned (Haas \& Rowe 1999). Systematic affinities of the fossils were initially determined by consulting references such as Cutler \& Gregory (1998), Metcalfe \& Chalk (1950, 1989), Metcalfe (1987), Ilic (1991) and searches of the computerised OPCN (Wheeler et al. 1986; LaPasha \& Wheeler 1987) and CSIRO Family Key (Ilic 1987) wood databases. Subsequently, comparisons were made with extant wood samples housed in the Jodrell Laboratory, Royal Botanic Gardens Kew; the Wood Anatomy Section in the Herbarium, Utrecht University; and the Federal Research Centre for Forestry and Forest Products, Hamburg.

The wood was described and measurements undertaken in accordance with the IAWA recommendations (IAWA Committee 1989) wherever possible. Vessel element lengths were measured from thin sections as macerations were not possible for the fossils. The fossil specimens are deposited at the British Antarctic Survey, Cambridge, United Kingdom. 


\section{RESULTS}

Order: Laurales

Family: Lauraceae

Tribe: Laureae

Organ genus: Sassafrasoxylon Brezinová et Süss

Generic diagnosis (translated from the German) - Vessels ring-porous, with a multiple ring of earlywood pores; perforation plates simple and scalariform; intervessel pits alternate and bordered. Parenchyma sparsely paratracheal. Rays homogeneous to weakly heterogeneous; uniseriate to quadriseriate; vessel ray pits enlarged, rounded to horizontally elongated and unilaterally bordered; oil idioblasts present.

Type species - Sassafrasoxylon lipnicense Brezinová et Süss (1988) from the Miocene of Lipnice, Czech Republic.

\section{Sassafrasoxylon gottwaldii sp. nov.}

Holotype: DJ. 1051.5

Paratype: DJ. 451.6

Repository: British Antarctic Survey, Cambridge, U.K.

Type locality: Seymour Island, Antarctica, $064^{\circ} 15^{\prime} 53^{\prime \prime} \mathrm{S}, 056^{\circ} 45^{\prime} 01^{\prime \prime} \mathrm{W}$.

Stratigraphic horizon: López de Bertodano Formation, Maastrichtian.

Etymology: The specific epithet recognizes Professor H. Gottwald and his extensive studies of fossil and extant woods.

Species diagnosis - Growth rings distinct, demarcated by an obvious change in vessel diameter (Fig. 2, 4). Wood ring-porous. Earlywood and latewood vessels mostly circular, solitary and occasionally paired, rarely in radial multiples or clusters of up to three pores; vessel walls are thicker in latewood than in earlywood (Fig. 4). Earlywood tangential vessel diameter medium, mean c. $110 \mu \mathrm{m}$ (range: 60-155 $\mu \mathrm{m}$ ); latewood tangential vessel diameter small, mean c. $30 \mu \mathrm{m}$ (range: $13-58 \mu \mathrm{m})$; mean vessel element length is $270 \mu \mathrm{m}$ (range: $140-550 \mu \mathrm{m}$ ) in earlywood and $300 \mu \mathrm{m}$ (range: $172-$ $520 \mu \mathrm{m}$ ) in latewood; mean vessel frequency $29 \mathrm{~mm}^{-2}$ (range: $20-33 \mathrm{~mm}^{-2}$ ) in earlywood and $41 \mathrm{~mm}^{-2}$ (range: $24-54 \mathrm{~mm}^{-2}$ ) in latewood. Perforation plates simple (Fig. 10), very rare scalariform perforations, with relatively few (i.e. < 15) thick bars, (in addition to simple perforations) present in narrow latewood vessels (Fig. 12). No helical thickenings were observed. Intervessel pitting alternate (Fig. 13, 14), very occasionally opposite; pits circular to polygonal, horizontal pit diameter 5-10 $\mu \mathrm{m}$. Vessel-ray pits with reduced borders, similar to intervessel pits in size and arrangement, rounded to occasionally gash-like, circular to more horizontally elongate (c. 8$13 \mu \mathrm{m})$, occasionally crowded within the cross fields [type 1 of Richter (1981)]. Fibres are distributed in more or less regular radial files especially in the latewood (Fig. 2, 4) although they are not always quadrangular in cross section. Mean fibre diameter is $11 \mu \mathrm{m}$ (range: $5-25 \mu \mathrm{m}$ ). The mean combined fibre wall thickness is 
$6.5 \mu \mathrm{m}$ (range: $2.5-12.5 \mu \mathrm{m}$ ) but no fibre pitting was observed. Axial parenchyma is more obvious in latewood when compared with the earlywood; in the latewood the parenchyma is paratracheal vasicentric to occasionally confluent (Fig. 2, 4); in the earlywood it forms a multiseriate initial band including one to several rows of earlywood vessels (Fig. 2). The parenchyma has up to c. 30 cells per axial strand. Rays multiseriate, mainly 2-4(-5) cells wide; mean height $310 \mu \mathrm{m}$ (range: $120-470$ $\mu \mathrm{m}$ ), mixed with few uniseriate rays of mean height $130 \mu \mathrm{m}$ (range: 70-200 $\mu \mathrm{m}$; Fig. 8). Rays are composed either solely of procumbent cells (homocellular) or of procumbent body cells with generally one, very occasionally two, rows of square to upright marginal cells [heterocellular; Kribs Heterogeneous Types II and III (Kribs 1935); Fig. 6]. There are between 4 and 8 rays per tangential $\mathrm{mm}$. No deposits or thickened cell walls were observed in the rays. Oil and/or mucilage cells were observed in association with marginal ray cells (Fig. 17, 18), in a single instance also with axial parenchyma (Fig. 15).

\section{DISCUSSION}

\section{Systematic affinities}

Richter (1981) has studied the anatomy of 41 Lauraceae genera (830 species, over 1600 specimens). Generally wood of the Lauraceae is characterised by 1) paratracheal parenchyma, 2) alternate intervascular pitting, 3) tyloses, 4) fibre pits exclusively in the radial walls except for the Beilschmiedia /Cryptocarya group (Richter 1981; Richter in Metcalfe 1987). The majority of lauraceous woods have diffuse-porous wood (ring-porous only in Sassafras), rays that are 2-4 cells wide, less than $1 \mathrm{~mm}$ high and more or less heterogeneous (Kribs Heterogeneous Types I and II), and oil and/or mucilage cells in the form of idioblasts (Richter 1981; Richter in Metcalfe 1987).

The wood of Sassafras is similar to most other members of the Lauraceae in having alternate pitting (Fig. 16), simple perforation plates (Fig. 9), paratracheal parenchyma (Fig. 1,3) oil and/or mucilage cells (Fig. 5, 7). However, Sassafras differs from other Lauraceae in having the combination of distinctly ring-porous wood (Fig. 1, 3), simple (Fig. 9) perforation plates but occassionally scalariform (with few, i.e. $<10$, bars; Fig. 11) in latewood vessels and commonly 4- or 5-seriate rays (Fig. 7). The fossils both exhibit scalariform perforation plates with slightly more bars (i.e. up to 11) than extant Sassafras. Other than this there is no significant difference in wood structural features, qualitatively or quantitatively, between the fossils and the three extant species of Sassafras [S. albidum (Nutt.) Nees of eastern North America, $S$. randaiense (Hayata) Rehder of Taiwan and S. tzumu Hemsley of mainland China]. The extant species of Sassafras are indistinguishable from each other in terms of wood anatomy therefore we cannot assign the Cretaceous fossils to a single extant species. Moreover, it cannot be assumed that these Sassafras-like fossils belong to the extant genus as they were found as isolated pieces of wood and may represent a stem taxon or another lauraceous genus that developed growth rings in a seasonal, polar environment. 

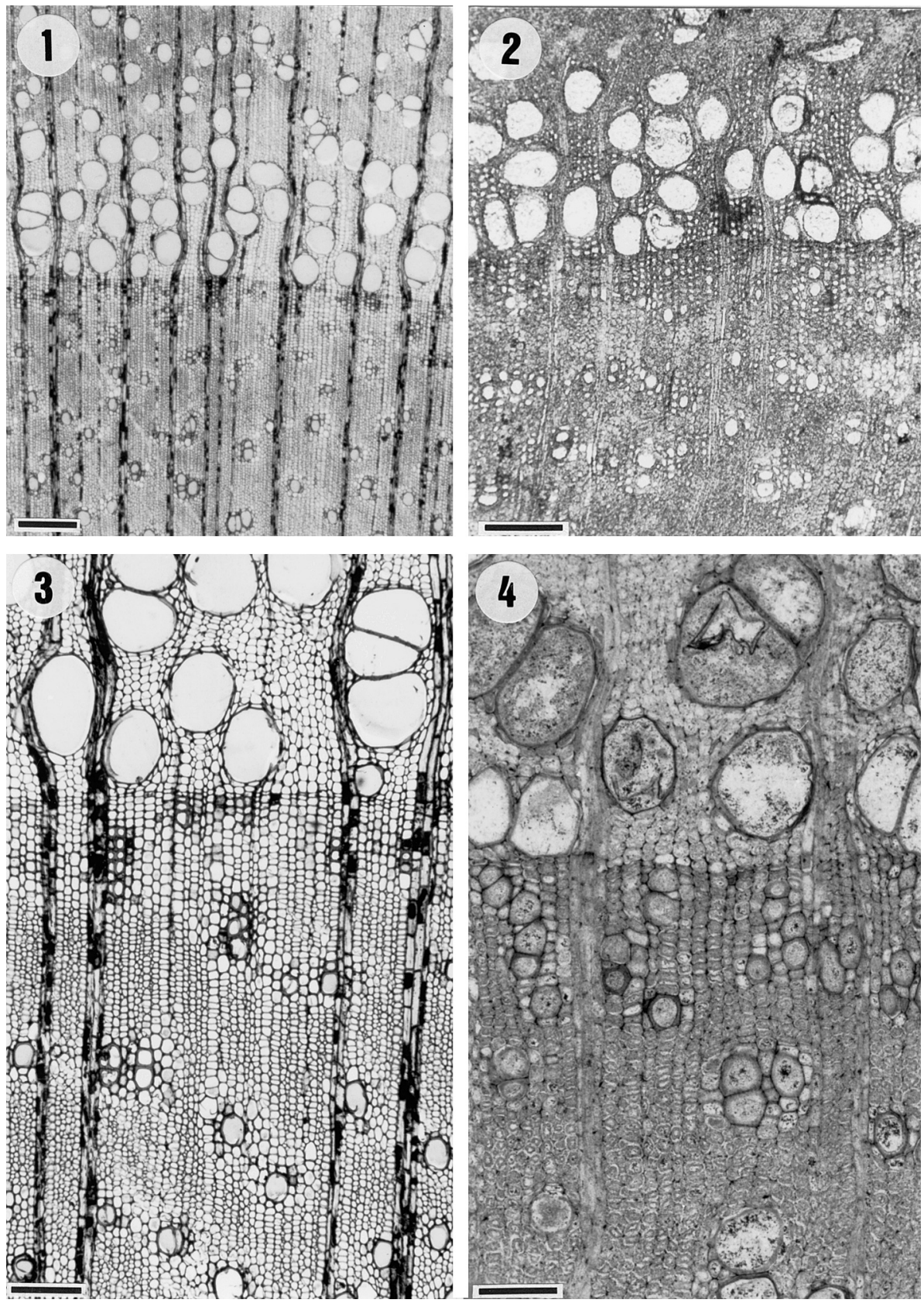

Fig. 1-4. Transverse sections of extant Sassafras and fossil Sassafrasoxylon. - 1 \& 3: Sassafras albidum (Kew: 8/52 No. 2 Stern). - 2 \& 4: Sassafrasoxylon gottwaldii (DJ. 451.6). - Scale bars $=200 \mu \mathrm{m}$ in Fig. $1 \& 2 ; 100 \mu \mathrm{m}$ in Fig. $3 \& 4$. 

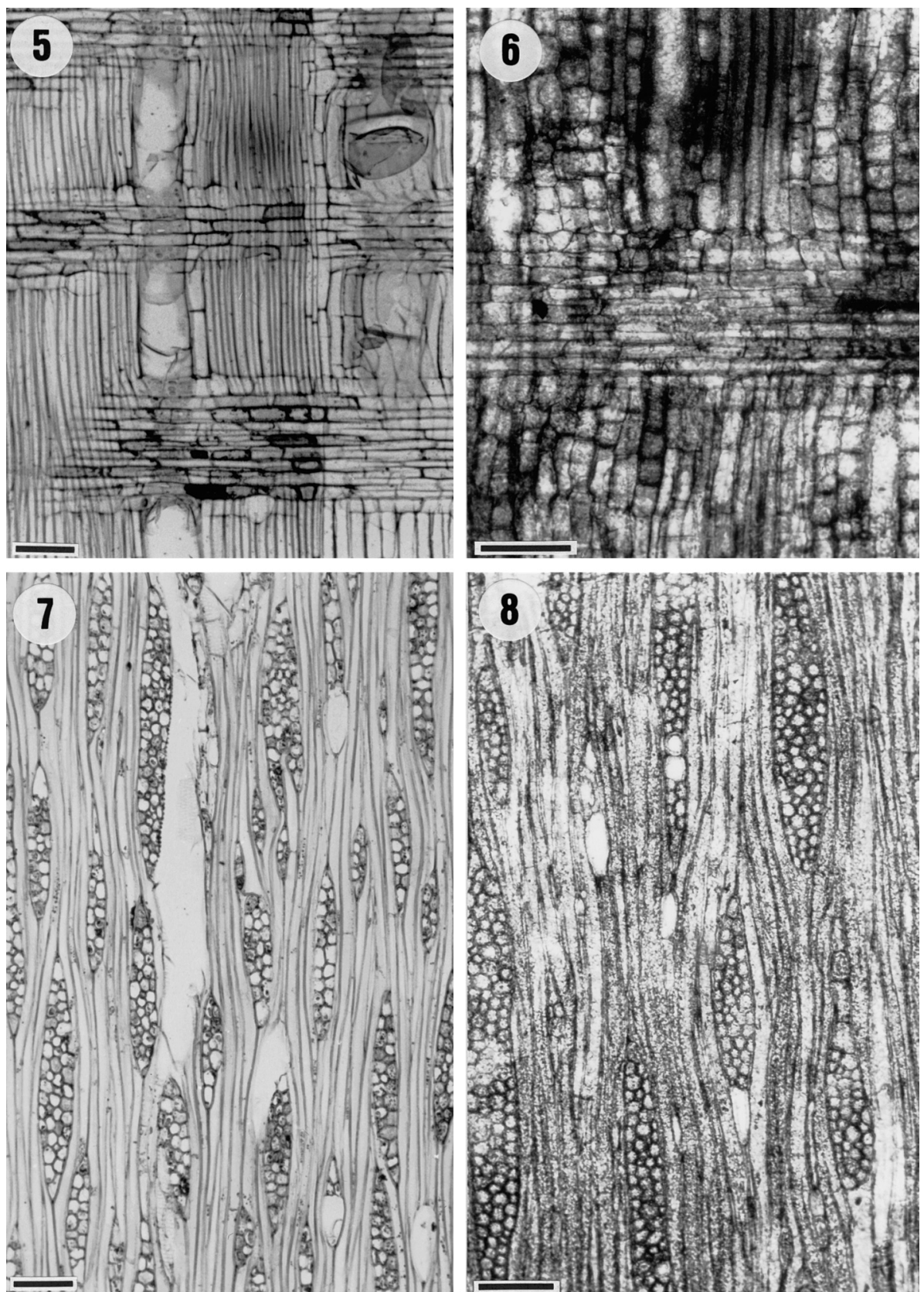

A.

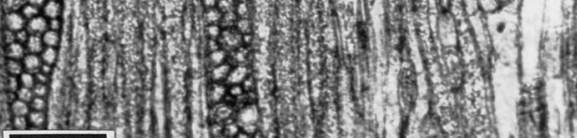

Fig. 5-8. Longitudinal sections of extant Sassafras and fossil Sassafrasoxylon. - 5: Radial section of Sassafras randaiense (Kew: Mus IV Formosa). - 6: Radial section of Sassafrasoxylon gottwaldii (DJ. 1051.5). - 7: Tangential section of Sassafras albidum (Kew: 8/52 No. 2 Stern). - 8: Tangential section of Sassafrasoxylon gottwaldii (DJ. 1051.5). - Scale bar $=75 \mu \mathrm{m}$. 


\section{Fossil lauraceous woods}

Fossil woods of Lauraceae are known from North America (e.g. Page 1967, Wheeler et al. 1977; Scott \& Wheeler 1982; Herendeen 1991), South America (Kräusel 1925; Nishida et al. 1988, 1990), Antarctica (Gothan 1908), India (Lakhanpal et al. 1981; Awasthi \& Jafar 1990), Australia (e.g. Leisman 1985; Hill 1986; Christophel et al. 1987; Carpenter et al. 1994; MacPhail et al. 1994) and Europe (e.g. Felix 1883; Süss 1958; Süss \& Madel 1958; Huard 1967; Prakash et al. 1971; Brezinová \& Süss 1988; Gottwald 1992, 1997). There have been a number of organ genera erected for woods of lauraceous affinity. However, many were synonimised with Laurinium Unger by Edwards (1931) although Ulminium Unger (1842) has nomenclatural priority. Süss (1958) and later Gottwald (1992) critically re-evaluated fossil lauraceous woods and listed those species with dubious, as well as certain, affinity to members of the Lauraceae. Brezinová and Süss (1988) described a lauraceous fossil wood from the Miocene of the Czech Republic with anatomical similarity closest to that of extant Sassafras. Consequently they erected the organ genus Sassafrasoxylon for their material. The Antarctic fossils described herein are very similar to the type species and can be included in the organ genus with no emendment to the generic diagnosis. The Antarctic material differs from the type species only in quantitative measurements (e.g. triseriate as opposed to quadriseriate maximum ray width, vessel diameters etc.) which could be accounted for by natural variation. However, the differences in age and geographical location support the erection of a new species of Sassafrasoxylon for the Antarctic material.

\section{Distribution}

Lauraceae fossils, other than wood, are common in Cretaceous and Tertiary sediments of both the Northern and Southern Hemispheres (e.g. Drinnan et al. 1990; Pole 1993; Hill \& Merrifield 1993; Herendeen et al. 1994; Carpenter \& Pole 1995; Pole 1996; Beertini \& Roiron 1997; Kvacek 1998; Eklund \& Kvacek 1998; Pole \& Douglas 1999; Herendeen et al. 1999) but the fossil record of Sassafras-like organs is restricted to leaves from the Tertiary of North America (Axelrod 1966; MacGinitie 1953), Europe and Asia (Mai 1995). The fossil wood from Upper Cretaceous sediments of the Antarctic Peninsula region is the first and earliest record of Sassafras-like wood. Its presence in Antarctica may 1) suggest a minimum divergence age of c. 83 million years for the genus Sassafras, or its stem taxon, and 2) imply that this taxon was more widespread in the geological past and has experienced extinction over much of its range.

Today, the Lauraceae consists of about 50 genera and approximately 2500 to 3000 species generally with an arboreal habit, rarely shrubs, distributed throughout tropical and warm temperate regions, with tropical Indo-Malaya and tropical South America being the two major areas of concentration (Richter in Metcalfe 1987; Van der Werff \& Richter 1996; Mabberley 1997). They are present in wet forest at all altitudes and are frequently one of the most common tree families especially in the foothills and middle elevations of the Andes (Van der Werff \& Richter 1996). Members of the genus Sassafras (three species) are restricted today to East Asia and northeastern North America (Mabberley 1997). The North American Sassafras albidum (Nutt.) 

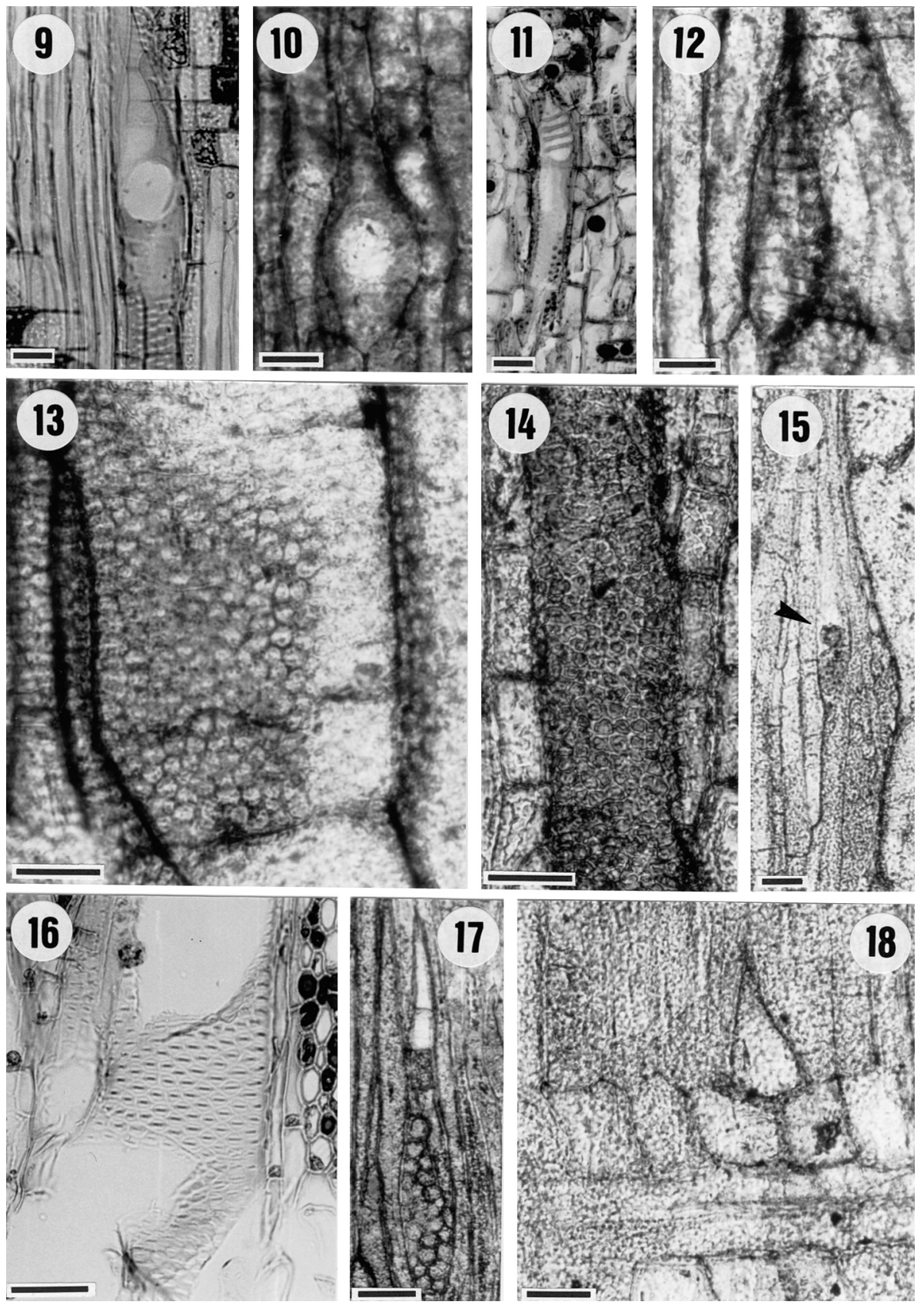

Fig. 9-18. Longitudinal sections of extant Sassafras and fossil Sassafrasoxylon. - 9: Simple perforation plate in the latewood of Sassafras albidum (Kew: 8/52 No. 2 Stern). - 10: Ditto of Sassafrasoxylon gottwaldii (DJ. 1051.5). - 11: Scalariform perforation plate in latewood of Sassafras tzumu (Kew: Hemsl WL Stern No. 258 7/52). - 12: Ditto of Sassafrasoxylon gottwaldii 
Nees is a shrub or medium-sized aromatic tree that tends to form thickets in moist upland or valley habitats often in clearings. It is fast growing but short lived and has a spreading crown of short, stout branches with distinctive leaves. This species is the northernmost representative of the Lauraceae (Little 1998). Sassafras tzumu and $S$. randaiense are from East Asia; the former common in central and southern China at altitudes from 500 to $1000 \mathrm{~m}$. The latter occurs only as scattered individuals in the broad-leaved forests of the Central Ranges in Taiwan at altitudes of 900 to $2400 \mathrm{~m}$ (Li 1963). Both are described as medium-sized deciduous trees and are similar in habit, vegetative characters, inflorescences and fruits to Sassafras albidum (Rehder 1920).

The fast growing nature and ability to tolerate poor soils may have helped the northward migration. Sassafras would not have been out of place in a postulated warm temperate environment (e.g. Crame 1992; Hill \& Scriven 1995; Dingle \& Lavelle 1998 and the references cited therein; Francis 1999) with suggested mean annual temperatures of $8-15^{\circ} \mathrm{C}$, a possible temperature range of less than $16^{\circ} \mathrm{C}$, no frosts and high annual rainfall (Birkenmajer \& Zastawniak 1989; Askin 1992). These conditions are similar to those experienced by Sassafras today. Evidence in support of a temperate climate at $\mathrm{c} .60^{\circ} \mathrm{S}$ in the Cretaceous can also be obtained from the presentday ecological ranges of the nearest living relatives of other fossil plant material which have been found from similar localities, e.g. Podocarpaceae (Dettmann 1989), Atherospermataceae (Poole \& Francis 1999), Winteraceae (Poole \& Francis 2000), Cunoniaceae (Poole et al. 2000), Nothofagaceae (e.g. Torres 1984; Askin 1992), Aquifoliaceae (Dettmann 1989) and Myrtaceae (Dettmann \& Thomson 1987).

\section{CONCLUSIONS}

A new species, Sassafrasoxylon gottwaldii, has been erected for Late Cretaceous fossil woods from the northern Antarctic Peninsula region with anatomical characters indistinguishable from extant Sassafras Nees \& Eberm. of the Lauraceae. This is the earliest occurrence, and only record in the Southern Hemisphere, of an organ with features closest to Sassafras now restricted to the Northern Hemisphere. This record may suggest that Sassafras, or its stem taxon, first appeared in Gondwana and later radiated into the Northern Hemisphere. Therefore the modern distribution of Sassafras may represent a relict of a more geographically widespread taxon in the past. The presence of this taxon in the Late Cretaceous sediments of James Ross Island and Seymour Island helps confirm (e.g. Dingle \& Lavelle 1998 and references cited therein) the prevalence of a warm temperate climate for the Antarctic Peninsula at the end of the Mesozoic. This record furthers our understanding of a biodiversity and climate no longer represented today.

(DJ. 1051.5). - 13 \& 14: Alternate intervessel pitting in Sassafrasoxylon gottwaldii (DJ. 1051.5). - 15: Oil cell (arrowed) in Sassafrasoxylon gottwaldii (DJ. 1051.5). - 16: Alternate intervessel pitting in Sassafras albidum (Kew: 8/52 No. 2 Stern). - 17 \& 18: Oil cells as-sociated with rays in Sassafrasoxylon gottwaldii (DJ. 1051.5 \& DJ. 451.6 respectively). - Scale bars $=20 \mu \mathrm{m}$ in Fig. 9-12; $30 \mu \mathrm{m}$ in Fig. 13-15; $50 \mu \mathrm{m}$ in Fig. 16-18. 


\section{ACKNOWLEDGEMENTS}

We thank the British Antarctic Survey for the loan of the fossil wood specimens and for the invitation to I.P. to collect material. The Trans-Antarctic Association is also thanked for contribution to field expenses. The continued help of Drs D.F. Cutler, P. Rudall and A.M.W. Mennega in allowing access to the modern wood slide collections housed in the Jodrell Laboratory, Royal Botanic Gardens, Kew, and the Herbarium, University of Utrecht, respectively, is greatly appreciated. Drs D. Cantrill, P.S. Herendeen, S. Manchester and E.A. Wheeler are thanked for their constructive comments. This research is made possible by NERC funding which is here gratefully acknowledged.

\section{REFERENCES}

Askin, R. 1992. Late Cretaceous-Early Tertiary Antarctic outcrop evidence for past vegetation and climates. Antarct. Res. Ser. 56: 61-73.

Awasthi, N. \& S. A. Jafar. 1990. First fossil wood (Lauraceae) from Baratang, Andaman Nicobar Islands, India. Current Sci. 59: 1243-1244.

Axelrod, D.I. 1966. The Eocene Copper Basin flora of northeastern Nevada. Univ. Calif. Publ. Geol. Sci. 59: 1-124.

Beertini, A. \& P. Roiron. 1997. Vegetational and climatic evolution during the middle Pliocene n central Italy: the contribution of palynology and macroflora to the study of the upper Valdarno basin (Santa Barbara section). C. R. séances Acad. Sci. ser. II. 324: 763-771.

Birkenmajer, K. \& E. Zastawniak. 1989. Late Cretaceous - Early Neogene vegetation history of the Antarctic Peninsula sector, Gondwana break-up and Tertiary glaciations. Bull. Polish Acad. Sci. Earth Sci. 37: 63-88.

Brezinová, D. \& H. Süss. 1988. Nadel- und Laubholzreste aus miozänen Hornsteinen von Lipnice, CSSR. Feddes Repert. 99: 279-289.

Carpenter, R. J., R.S. Hill \& G. J. Jordan. 1994. Cenozoic vegetation in Tasmania: macrofossil evidence. In: R.S. Hill (ed.), History of the Australian vegetation Cretaceous to Recent: 276-298. Cambridge University Press, Cambridge.

Carpenter, R. J. \& M. Pole. 1995. Eocene plant fossils from the Lefroy and Cowan paleodrainages, western Australia. Austr. Syst. Bot. 8: 1107-1154.

Christophel, D.C., W.K. Harris \& A.K. Syber. 1987. The Eocene flora of the Anglesea locality, Victoria. Alcheringa 11: 303-323.

Crame, J.A. 1992. Evolutionary history of polar regions. Histor. Biol. 6: 37-60.

Crame, J.A., J.M. McArthur, D. Pirrie \& J.B. Riding. 1999. Strontium isotope correlation of the basal Maastrichtian Stage in Antarctica to the European and US biostratigraphic schemes. J. Geol. Soc. Lond. 156: 957-964.

Crame, J.A., D. Pirrie, J.B. Riding \& M.R.A. Thomson. 1991. Campanian Maastrichtian (Cretaceous) stratigraphy of the James Ross Island area, Antarctica. J. Geol. Soc. 148: 11251140.

Cutler, D.F. \& M. Gregory. 1998. Anatomy of the dicotyledons. Volume IV. Saxifragales. Clarendon Press, Oxford.

Dettman, M.E. 1989. Antarctica: Cretaceous cradle of austral temperate rainforests? In: J.A. Crame (ed.), Origins and Evolution of the Antarctic Biota: 89-106. Geological Society Special Publication No. 47, London.

Dettmann, M.E. \& M.R.A. Thomson. 1987. Cretaceous palynomorphs from the James Ross Island area, Antarctica - a pilot study. Brit. Antarct. Surv. Bull. 77: 13-59.

Dingle, R.V. \& M. Lavelle. 1998. Late Cretaceous-Cenozoic climatic variations of the northern Antarctic Peninsula: new geochemical evidence and review. Palaeogeogr., Palaeoclimatol., Palaeoecol. 141: 215-232. 
Drinnan, A.N., P.R. Crane, E.M. Friis \& K.R. Pedersen. 1990. Lauraceous flowers from the Potomac group (mid Cretaceous) of eastern North America. Bot. Gaz. 151: 370-384.

Edwards, W.N. 1931. Dicotyledons. In: W. Jonkmanns (ed.), Fossilum catalogus. Linga, Berlin.

Eklund, H. \& J. Kvacek. 1998. Lauraceous inflorescences and flowers from the Cenomanian of Bohemia (Czech Republic, central Europe). Int. J. Plant Sci. 159: 668-686.

Felix, J. 1883. Untersuchungen über fossile Hölzer. Zeit. Deut. Geol. Gesell. 35: 59-91.

Francis, J.E. 1986. Growth rings in Cretaceous and Tertiary wood from Antarctica and their palaeoclimatic implications. Palaeontology 29: 665-684.

Francis, J.E. 1996. Antarctic palaeobotany: clues to climate change. Terra Antarct. 3: 135-140.

Francis, J.E. 1999. Evidence from fossil plants for Antarctic palaeoclimates over the past 100 million years. Terra Antarctica Rep. 3: 43-52.

Gothan, W. 1908. Die fossilen Hölzer von der Seymour- und Snow Hill-Insel. Schwed. Südpolar Exped. 1901-1903 3: 1-33.

Gottwald, H. 1992. Hölzer aus Marinen Sanden des Oberen Eozän von Helmstedt (Niedersachsen). Palaeontograph. B 225: 27-103.

Gottwald, H. 1997. Alttertiäre Kieselhölzer aus miozänen Schottern der ostbayerischen Molasse bei Ortenburg. Documenta Naturae 109: 1-82.

Hass, H. \& N.P. Rowe. 1999. Thin sections and wafering. In: T.P. Jones \& N.P. Rowe (eds.), Fossil plants and spores: modern techniques: 76-81. Geological Society, London.

Herendeen, P.S. 1991. Lauraceous wood from the mid-Cretaceous Potomac group of eastern North America: Paraphyllanthoxylon marylandense sp. nov. Rev. Palaeobot. Palynol. 69: 277-290.

Herendeen, P.S., W.L. Crepet \& K.C. Nixon. 1994. Fossil flowers and pollen of Lauraceae from the upper Cretaceous of New Jersey. Plant Syst. Evol. 189: 29-40.

Herendeen, P.S., S. Magallon-Puebla, R. Lupia, P.R. Crane \& J. Kobylinska. 1999. A preliminary conspectus of the Allon flora from the Late Cretaceous (Late Santonian) of central Georgia, USA. Ann. Missouri Bot. Gard. 86: 407-471.

Hill, R.S. 1986. Lauraceous leaves from the Eocene of Nerriga, New South Wales. Alcheringa 10: $327-351$.

Hill, R.S. \& H.E. Merrifield. 1993. An early Tertiary macroflora from West Dale, Southwestern Australia. Alcheringa 17: 285-326.

Hill, R.S. \& L. J. Scriven. 1995. The angiosperm-dominated woody vegetation of Antarctica: a review. Rev. Palaeobot. Palynol. 86: 175-198.

Huard, J. 1967. Étude de trois bois de Lauracées fossiles des formations à lignite Neogénes d'Arjuzanx (Landes). Rev. Gen. Bot. 74: 81-105.

IAWA Committee. 1989. IAWA list of microscopic features for hardwood identification. IAWA Bull. n. s. 10: 219-332.

Ilic, J. 1987. The CSIRO family key for hardwood identification. E. J. Brill, Leiden.

Ilic, J. 1991. CSIRO atlas of hardwoods. Crawford House Press and CSIRO Publications, Australia.

Keating, J.M. 1992. Palynology of the Lachman Crags Member, Santa-Marta Formation (Upper Cretaceous) of north-west James Ross Island. Antarct. Sci. 4: 293-304.

Kräusel, R. 1925. Beiträge zur Kenntnis der fossilen Flora Südamericas. I. Fossile Hölzer aus Patagonien und benachbarten Gebieten. Archiv. Bot. Svensk. Vetensk. 19: 1-36.

Kribs, D.A. 1935. Salient lines of structural specialization in the wood rays of dicotyledons. Bot. Gaz. 96: 547-557.

Kvacek, Z. 1998. Bilina: a window on Early Miocene marshland environments. Rev. Palaeobot. Palynol. 101: 111-123. 
Lakhanpal, R.N., U. Prakash \& N. Awasthi. 1981. Some more dicotyledonous woods from the Tertiary of Deomali, Arunachal Pradesh, India. The Palaeobot. 27: 232-252.

LaPasha, C.A. \& E.A. Wheeler. 1987. A microcomputer based system for computer-aided wood identification. IAWA Bull. n.s. 8: 347-354.

Leisman, G.A. 1985. A fossil lauracean (Cryptocarya) wood from the Tertiary of eastern Victoria, Australia. Amer. J. Bot. 72: 896.

Li, H.L. 1963. The woody flora of Taiwan. Livingstone Publishing Company, Narberth, Pennsylvania.

Little, E.L. 1998. National Audubon Society field guide to North American trees. Chanticleer Press Inc., New York.

Mabberley, D. J. 1997. The plant-book. A portable dictionary of the vascular plants. $2^{\text {nd }}$ Ed. Cambridge University Press, Cambridge.

MacGinitie, H.D. 1953. Fossil plants of the Florissant Beds, Colorado. Publ. Carnegie Inst. Wash. 599: 1-197.

MacPhail, M.K., N.F. Alley, E.M. Truswell \& I.R.K. Sluiter. 1994. Early Tertiary vegetation: evidence from spores and pollen. In: R.S. Hill (ed.), History of the Australian vegetation - Cretaceous to Recent: 189-261. Cambridge University Press, Cambridge.

Mai, D. 1995. Tertiäre Vegetationsgeschichte Europas. Gustav Fischer, Jena.

Metcalfe, C.R. 1987. Anatomy of the dicotyledons: Vol. III Magnoliales, Illiciales and Laurales. $2^{\text {nd }}$ Ed. Clarendon Press, Oxford.

Metcalfe, C.R. \& L. Chalk. 1950. Anatomy of the dicotyledons Vol. I \& II. Clarendon Press, Oxford.

Metcalfe, C.R. \& L. Chalk. 1989. Anatomy of the dicotyledons: Vol. II Wood structure and conclusion of the general introduction. $2^{\text {nd }}$ Ed. Clarendon Press, Oxford.

Nishida, M., H. Nishida \& T. Nasa. 1988. Anatomy and affinities of the petrified plants from the Tertiary of Chile V. Bot. Mag. Tokyo 101: 293-309.

Nishida, M., T. Ohsawa \& H. Nishida. 1990. Anatomy and affinities of the petrified plants from the Tertiary of Chile VI. Bot. Mag. Tokyo 103: 255-268.

Page, V.M. 1967. Angiosperm wood from the Upper Cretaceous of central California. Part 1. Amer. J. Bot. 54: 510-514.

Pirrie, D. 1994. Petrography and provenance of the Marambio Group, Vega Island, Antarctica. Antarct. Sci. 6: 517-527.

Pirrie, D., J.A. Crame \& J.B. Riding. 1991. Late Cretaceous stratigraphy and sedimentology of Cape Lamb, Vega Island, Antarctica. Cret. Res. 12: 227-258.

Pole, M. 1993. Early Miocene flora of the Manuherikia group, New Zealand. 6. Lauraceae. J. Roy. Soc. New Zealand 23: 303-312.

Pole, M. 1996. Plant macrofossils from the Foulden Hills Diatomite (Miocene), central Otago, New Zealand. J. Roy. Soc. New Zealand 26: 1-39.

Pole, M. \& B. Douglas. 1999. Plant macrofossils of the upper Cretaceous Kaitangata coalfield, New Zealand. Austr. Syst. Bot. 12: 331-364.

Poole, I., D. J. Cantrill, P. Hayes \& J.E. Francis. 2000. The fossil record of Cunoniaceae: new evidence from Late Cretaceous fossil wood of Antarctica. Rev. Palaeobot. Palynol. 111: $127-144$.

Poole, I. \& J.E. Francis. 1999. The first record of fossil atherospermataceous wood from the upper Cretaceous of Antarctica. Rev. Palaeobot. Palynol. 107: 97-107.

Poole, I. \& J.E. Francis. 2000. The first record of Winteraceae wood from the Cretaceous of Antarctica. Ann. Bot. 85: 307-315.

Prakash, U., D. Brezinová \& C. Buzek. 1971. Fossil woods from the Doupovske Hory and Ceske Stredohori Mountains in northern Bohemia. Palaeontograph. B 133: 103-128. 
Rehder, A. 1920. The American and Asiatic species of Sassafras. J. Arnold Arbor. 1: 242-245.

Richter, H.G. 1981. Anatomie des sekundären Xylems und der Rinde der Lauraceae. Sonderbände des Naturwissenschaftlichen Vereins Hamburg No. 5: 1-148.

Scott, R.A. \& E.A. Wheeler. 1982. Fossil woods from the Eocene Clarno Formation of Oregon. IAWA Bull. n.s. 3: 135-154.

Süss, H. 1958. Anatomische Untersuchungen über die Lorbeerhölzer aus dem Tertiär des Hasenberges bei Wiesa in Sachsen. Abh. Deut. Akad. Wiss. Berlin Jahrb. 1956, 1: 1-59.

Süss, H. \& E. Mädel. 1958. Über Lorbeerhölzer aus miozänen Schichten von Randeck (Schwäbische Alb) und Ipolytarnóc (Ungarn). Geologie 7: 80-99.

Torres, T. 1984. Nothofagoxylon antarcticus n. sp., madera fósils del Terciario de la isla Rey Jorge, islas Shetland del Sur, Antártica. Ser. Cient. INACH 31: 39-52.

Truswell, E.M. 1991. Antarctica: a history of terrestrial vegetation. In: R. J. Tingey (ed.), The Geology of Antarctica: 135-163. Oxford University Press, New York.

Unger, G. 1842. Synopsis Lignorum fossilium Plantarum Acramphibryarum. In: S. Endlicher (ed.), Genera plantarum, Suppl. II. Appendix: 100-102. Wien.

Van der Werff, H. \& H.G. Richter. 1996. Towards an improved classification of Lauraceae. Ann. Missouri Bot. Gard. 83: 409-418.

Wheeler, E.A., R.G. Pearson, C.A. LaPasha, T. Zack \& W. Hatley. 1986. Computer-aided wood identification. Raleigh: North Carolina Agricultural Research Service Bulletin 474.

Wheeler, E.A., R.A. Scott \& E.S. Barghoorn. 1977. Fossil dicotyledonous woods from Yellowstone National Park. J. Arnold Arbor. 58: 280-302. 